\title{
The effect of differing types of cloth and of contamination by non-feed nitrogen on intestinal digestion estimates using porous synthetic-fibre bags in a cow
}

\author{
BY TUOMO VARVIKK O* AND AILA VANHATALO \\ Institute of Animal Production, Agricultural Research Centre (MTTK), SF-31600 Jokioinen, \\ Finland
}

(Received 2 August 1989 - Accepted 27 October 1989)

\begin{abstract}
The influence of free surface area and pore size of a synthetic-fibre bag, and flow of intestinal substances into the bag, on the intestinal digestion estimates by the nylon-bag method of dry matter (DM), neutral detergent fibre (NDF), nitrogen, NDF-N and feed ${ }^{15} \mathrm{~N}$ was studied using a non-lactating cow fed on hay supplemented with barley and oats at maintenance level. The bags containing ${ }^{15} \mathrm{~N}$-labelled ground ryegrass (Lolium perenne), barley, barley straw or rapeseed (Brassica napus) straw were introduced into the duodenum through a T-shaped cannula and collected from the faeces. Also, the disappearance of $\mathbf{N}$ from the bag was related to the true intestinal $N$ digestion by comparing it with the net loss between duodenum and faeces of ${ }^{15} \mathrm{~N}$ in ryegrass introduced into the duodenum in an aqueous suspension. It was noted that the bag cloth often significantly affected both disappearance values and the subsequent chemical composition of the residues. Re-analysing part of the data as a $2 \times 2$ factorial (free surface $\times$ pore size) suggested that free surface area was often more important than pore size as a determinant of both disappearance values and chemical composition. Lower apparent (Kjeldahl $N$ ) than true $\left({ }^{15} \mathrm{~N}\right)$ feed $\mathrm{N}$ disappearance from the bag suggested a notable proportion of non-feed $\mathrm{N}$ in the residues, especially with fibrous feeds with low $\mathbf{N}$. With ryegrass, ${ }^{15} \mathrm{~N}$ net loss within the intestine was lower than ${ }^{15} \mathrm{~N}$ disappearance from the bags. It was concluded that disappearance of Kjeldahl $\mathrm{N}$ is an underestimate of feed $\mathrm{N}$ disappearance from bags, but may possibly be an overestimate of the true intestinal digestion of feed $\mathbf{N}$.
\end{abstract}

Intestinal digestion: Nylon-bag technique: Ruminant intestine: Cow

In recent ruminant nutrition research, lower-gut digestion of individual feeds has been brought into focus. The nylon-bag technique, which has a wide acceptance for estimating the degradation of individual feed nutrients in the rumen, has also been applied in studying the post-gastric digestion of feeds in the pig (Petry \& Handlos, 1978; Sauer et al. 1983, 1987; Graham et al. 1985; Cherian et al. 1988) and in the ruminant (Voigt \& Piatkowski, 1983; Hvelplund, 1984, 1985; Voigt et al. 1985; Kirkpatrick \& Kennelly, 1985; Rooke, 1985). While the rumen-bag technique is rather well documented, the number of papers dealing with the intestinal-bag method, often called the mobile-bag method, is few.

The present study was designed to assess the influence of the type of bag cloth and flow of intestinal substances into the mobile bags within the ruminant intestine on degradation values of different types of intact feeds. To obtain a relevant reference value and to relate the disappearance of feed nitrogen from bags to true intestinal feed $\mathrm{N}$ digestion, the net loss between duodenum and faeces of feed $\mathrm{N}$ was estimated by using ${ }^{15} \mathrm{~N}$-labelled ryegrass (Lolium perenne).

\footnotetext{
* Present address: International Livestock Centre for Africa, P.O. Box 5689, Addis Ababa, Ethiopia.
} 


\section{MATERIALS AND METHODS}

Experimental animal and its feeding

One intestinally cannulated non-lactating cow of the Finnish Ayrshire breed (live weight $550 \mathrm{~kg}$ ) was used. The animal was given $4 \mathrm{~kg}$ grass hay and $1.75 \mathrm{~kg}$ barley-oats $(1: 1, \mathrm{w} / \mathrm{w})$. The content of $\mathrm{N}$ and neutral-detergent fibre (NDF; $\mathrm{g} / \mathrm{kg}$ dry matter (DM)) of the hay was 14 and 660 , the respective contents for the mix of barley and oats being 20 and 250 .

\section{Feedingstuffs incubated in bags}

The feedingstuffs were ryegrass, barley, barley straw and rapeseed (Brassica napus) straw, all internally labelled with ${ }^{15} \mathrm{~N}$, oven-dried and milled to pass a $1.0 \mathrm{~mm}$ screen. The details of feeds and their cultivation and chemical composition was previously described by Varvikko \& Lindberg (1985).

\section{Mobile-bag technique}

In the mobile-bag method, approximately $1.1 \mathrm{~g}$ (barley) or $0.8 \mathrm{~g}$ (ryegrass, barley straw or rapeseed straw) of milled ( $1 \mathrm{~mm}$ mesh) experimental feed was weighed into a small bag (external dimensions $35 \times 50 \mathrm{~mm}$ ) made of polyester (Polymon, Switzerland) with a ratio for free (open) surface area (\% of total surface) relative to pore size $(\mu \mathrm{m})$ of $(\% / \mu \mathrm{m}) 2: 1$, $2: 10,5: 6,5: 16,15: 30$ or $33: 41$. The bags were prepared and closed by a heat-sealing machine (Elwis-Pack, Denmark). Individual feeds were exposed to the duodenum in random order (ryegrass, rapeseed straw, barley straw and barley) at four consecutive $7 \mathrm{~d}$ collection (feed) periods. Different bag types were tested separately within each feed. Principally, two bags of each bag type were inserted into the duodenum with a spatula during the $12 \mathrm{~h}$ after morning feeding. At each time of introduction an average of three to four bags of different types were introduced into the duodenum, twelve bags a day. During the first $5 \mathrm{~d}$ of each collection (feed) period, ten bags ( $5 \mathrm{~d} \times 2$ bags) per each cloth type were introduced into the duodenum, making 240 bags ( 4 feeds $\times 6$ cloth types) for the entire experiment.

The bags collected from the faeces were washed for $1 \mathrm{~h}$ in a rotating cylinder with running tap water $\left(40^{\circ}\right)$, and dried in a forced-draft oven $\left(60^{\circ}, 24 \mathrm{~h}\right)$. Each bag was weighed, and thereafter three to four bags were randomly pooled on each occasion to form one sample. For each occasion three samples were collected to be analysed for DM, Kjeldahl $\mathrm{N},{ }^{15} \mathrm{~N}$ (Varvikko \& Lindberg, 1985), NDF (Van Soest \& Wine, 1967) and Kjeldahl N in NDF (NDF-N).

Net loss within the intestine of excess feed ${ }^{15} \mathrm{~N}$

To obtain a reference value for the true intestinal digestion of feed $\mathrm{N}$, net disappearance of excess feed ${ }^{15} \mathrm{~N}$ within the intestine was estimated. For this purpose, $250 \mathrm{~g} \mathrm{DM}$ of ${ }^{15} \mathrm{~N}$ labelled ground ryegrass was suspended in $1400 \mathrm{ml}$ water and the suspension was introduced into the proximal duodenum through the T-shaped cannula, in twenty equal portions and at 20 -min intervals, starting $2 \mathrm{~h}$ from the morning feed. During the subsequent $56 \mathrm{~h}$, twenty-one complete individual faecal samples were collected and contamination with urine was carefully avoided. Each faecal sample was weighed and analysed for DM, Kjeldahl $\mathrm{N}$ and ${ }^{15} \mathrm{~N}$. By subtracting the natural abundance of ${ }^{15} \mathrm{~N}(0 \cdot 3663$ of total $\mathrm{N}$ ) from the total ${ }^{15} \mathrm{~N}$ in ryegrass introduced into the duodenum and in faeces collected thereafter, the net loss of excess feed ${ }^{15} \mathrm{~N}$ between duodenum and faeces was calculated.

\section{Statistical analyses}

The effect of the free surface area:pore size of the bag cloth on the chemical composition of residual feeds and disappearance of feeds from the mobile bags was statistically analysed 
Table 1. Disappearance $(\mathrm{g} / \mathrm{kg})$ of dry matter $(D M)$, neutral-detergent fibre $(N D F)$, nitrogen, $N D F-N$ and ${ }^{15} N$, from ryegrass (Lolium perenne), barley, barley straw and rapeseed (Brassica napus) straw enclosed in nylon bags with varying free surface area:pore size $(\% / \mu m)$ during transit through the intestine

(Each value is the mean of three observations)

\begin{tabular}{|c|c|c|c|c|c|c|c|c|}
\hline $\begin{array}{l}\text { Free surface } \\
\text { area }: \text { pore size... }\end{array}$ & $2: 1$ & $2: 10$ & $5: 6$ & $5: 16$ & $15: 30$ & $33: 41$ & $\begin{array}{c}\text { SEM } \\
\text { (df I2) }\end{array}$ & $\begin{array}{c}\text { Statistical } \\
\text { significance } \\
\text { of cloth type }\end{array}$ \\
\hline \multicolumn{9}{|l|}{ Ryegrass } \\
\hline DM & $482^{\mathrm{a}}$ & $529^{a b}$ & $555^{b}$ & $551^{b}$ & $548^{b}$ & $563^{\mathrm{b}}$ & $13 \cdot 2$ & $* *$ \\
\hline $\mathrm{NDF}$ & 197 & 247 & 243 & 229 & 235 & 265 & $21 \cdot 0$ & NS \\
\hline $\mathrm{N}$ & 685 & 754 & 804 & 813 & 810 & 810 & $27 \cdot 5$ & $*$ \\
\hline NDF-N & 814 & 822 & 857 & 860 & 868 & 851 & $12 \cdot 5$ & NS \\
\hline${ }^{15} \mathrm{~N}$ & 749 & 828 & 869 & 862 & 866 & 865 & $28 \cdot 6$ & NS \\
\hline \multicolumn{9}{|l|}{ Barley } \\
\hline DM & $468^{\mathrm{a}}$ & $606^{b}$ & $790^{\circ}$ & $834^{\circ}$ & $825^{c}$ & $834^{c}$ & $11 \cdot 2$ & $* * *$ \\
\hline NDF & $347^{\mathrm{a}}$ & $365^{\mathrm{a}}$ & $444^{\mathrm{b}}$ & $509^{c}$ & $489^{b c}$ & $498^{\mathrm{c}}$ & $10 \cdot 3$ & $* * *$ \\
\hline $\mathrm{N}$ & $708^{a}$ & $814^{\mathrm{b}}$ & $885^{\mathrm{c}}$ & $906^{\mathrm{c}}$ & $897^{c}$ & $90 \mathrm{I}^{\mathrm{c}}$ & $10 \cdot 0$ & $* * *$ \\
\hline NDF-N & $628^{\mathrm{a}}$ & $627^{\mathrm{a}}$ & $734^{b}$ & $752^{\mathrm{b}}$ & $750^{\mathrm{b}}$ & $718^{\mathrm{b}}$ & 13.6 & $* * *$ \\
\hline${ }^{15} \mathrm{~N}$ & $766^{\mathrm{a}}$ & $853^{h}$ & $906^{\mathrm{e}}$ & $925^{\mathrm{e}}$ & $912^{\mathrm{e}}$ & $924^{c}$ & $9 \cdot 4$ & $* * *$ \\
\hline \multicolumn{9}{|l|}{ Barley straw } \\
\hline DM & $124^{\mathrm{a}}$ & $171^{b}$ & $177^{b}$ & $174^{b}$ & $185^{b}$ & $191^{\mathrm{b}}$ & 8.9 & ** \\
\hline NDF & 74 & 77 & 83 & 70 & 78 & 83 & $5 \cdot 3$ & NS \\
\hline $\mathrm{N}$ & 248 & 376 & 309 & 292 & 340 & 247 & $38 \cdot 9$ & NS \\
\hline NDF-N & $320^{b}$ & $196^{a b}$ & $290^{\mathrm{ab}}$ & $172^{\mathrm{ab}}$ & $255^{\mathrm{ab}}$ & $140^{\mathrm{a}}$ & 36.5 & $*$ \\
\hline${ }^{15} \mathrm{~N}$ & $586^{\mathrm{a}}$ & $675^{b}$ & $686^{\mathrm{b}}$ & $711^{\mathrm{D}}$ & $677^{b}$ & $684^{\mathrm{b}}$ & $10 \cdot 0$ & $* * *$ \\
\hline \multicolumn{9}{|l|}{ Rapeseed straw } \\
\hline DM & 144 & 166 & 184 & 204 & 179 & 169 & $15 \cdot 1$ & NS \\
\hline NDF & 70 & 59 & 67 & 75 & 68 & 61 & $9 \cdot 1$ & NS \\
\hline $\mathrm{N}$ & 246 & 228 & 349 & 413 & 433 & 318 & $58 \cdot 7$ & NS \\
\hline NDF-N & 155 & 149 & 102 & 161 & 259 & 153 & $54 \cdot 6$ & NS \\
\hline${ }^{15} \mathrm{~N}$ & 589 & 690 & 718 & 731 & 723 & 791 & $40 \cdot 3$ & NS \\
\hline
\end{tabular}

NS, not significant.

a. b.e Means in the same row with different superscript letters were significantly different $(P \leqslant 0 \cdot 05)$.

$* P \leqslant 0.05, * * P \leqslant 0.01, * * * P \leqslant 0.001$.

according to analysis of variance using the test of Tukey for the post-ANOVA treatment comparisons. As free surface area and pore size were confounded, the first four treatments $(2: 1,2: 10,5: 6$ and $5: 16(\% / \mu \mathrm{m})$ bags $)$ were re-arranged $2 \times 2$ factorially to test, according to analysis of variance with appropriate interactions, the importance in the method of free surface area $(2$ v. $5 \%)$ and pore size $(\operatorname{small}(1,6 \mu \mathrm{m}) \nu$. large $(10,16 \mu \mathrm{m}))$.

\section{RESULTS}

The average retention time of bags during transit through the intestine was 21 (SD 2.4) $\mathrm{h}$. The disappearance of DM, NDF, N, NDF-N and ${ }^{15} \mathrm{~N}$ from the feed in the bags, with the statistical significance of the effect of bag cloth, are presented in Table 1. Chemical compositions of the experimental feeds before and after intestinal digestion are given in Table 2. The significance of free surface area and pore size effects on disappearance and chemical composition of the feeds, after re-analysis of data $2 \times 2$ factorially, is given in Table 3 . The change in faecal ${ }^{15} \mathrm{~N}$ abundance during the $56 \mathrm{~h}$ collection period is shown in Fig. 1. 
Table 2. Chemical composition (neutral-detergent fibre (NDF) and nitrogen, $\mathrm{g} / \mathrm{kg}$ dry matter; $N D F-N$ and ${ }^{15} \mathrm{~N}, \mathrm{~g} / \mathrm{kg} \mathrm{N}$ ) of ryegrass (Lolium perenne), barley, barley straw and rapeseed (Brassica napus) straw before and after intestinal exposure in nylon bags with a varying free surface area:pore size $(\% / \mu m)$

(Each value is the mean of three observations)

\begin{tabular}{|c|c|c|c|c|c|c|c|c|c|}
\hline \multirow{2}{*}{$\begin{array}{l}\text { Free surface } \\
\text { area : pore size ... }\end{array}$} & \multirow{2}{*}{$\begin{array}{c}\text { Before } \\
\text { exposure }\end{array}$} & \multicolumn{6}{|c|}{ After exposure } & \multirow{2}{*}{$\begin{array}{c}\text { SEM } \\
\text { (df 12) }\end{array}$} & \multirow{2}{*}{$\begin{array}{c}\text { Statistical } \\
\text { significance } \\
\text { of cloth type }\end{array}$} \\
\hline & & $2: 1$ & $2: 10$ & $5: 6$ & $5: 16$ & $15: 30$ & $33: 41$ & & \\
\hline \multicolumn{10}{|l|}{ Ryegrass } \\
\hline NDF & 430 & $667^{a}$ & $687^{a b}$ & $730^{c}$ & $737^{\circ}$ & $726^{b c}$ & $723^{\mathrm{bc}}$ & $8 \cdot 4$ & $* * *$ \\
\hline $\mathbf{N}$ & 29 & 18 & 15 & 13 & 12 & 12 & 13 & $1 \cdot 4$ & NS \\
\hline$N D F-N$ & 322 & 192 & 244 & 236 & 242 & 223 & 252 & $17 \cdot 0$ & NS \\
\hline${ }^{15} \mathrm{~N}$ & 92 & 71 & 64 & 64 & 68 & 64 & 65 & 3.9 & NS \\
\hline \multicolumn{10}{|l|}{ Barley } \\
\hline NDF & 260 & $321^{\mathrm{a}}$ & $420^{\mathrm{a}}$ & $693^{b}$ & $771^{\mathrm{b}}$ & $759^{k}$ & $791^{\mathrm{b}}$ & $25 \cdot 3$ & $* * *$ \\
\hline $\mathrm{N}$ & 18 & 10 & 9 & 10 & 10 & 11 & 11 & $0 \cdot 4$ & NS \\
\hline NDF-N & 208 & $268^{a}$ & $418^{a b}$ & $489^{\mathrm{bc}}$ & $547^{\mathrm{bc}}$ & $506^{b c}$ & $598^{\circ}$ & $34 \cdot 6$ & $* *$ \\
\hline${ }^{15} \mathrm{~N}$ & 87 & $70^{\mathrm{ab}}$ & $65^{a}$ & $71^{\mathrm{ab}}$ & $70^{\mathrm{ab}}$ & $75^{\mathrm{k}}$ & $67^{a b}$ & 1.8 & $*$ \\
\hline \multicolumn{10}{|l|}{ Barley straw } \\
\hline NDF & 775 & $819^{a}$ & $863^{\mathrm{b}}$ & $864^{b}$ & $872^{\mathrm{b}}$ & $876^{b}$ & $878^{\mathrm{b}}$ & $6 \cdot 5$ & $* * *$ \\
\hline $\mathrm{N}$ & 6 & 5 & 4 & 5 & 5 & 5 & 5 & 0.2 & NS \\
\hline NDF-N & 465 & $420^{\mathrm{a}}$ & $601^{c}$ & $479^{\mathrm{ab}}$ & $546^{b c}$ & $524^{\mathrm{a} b}$ & $535^{b c}$ & $23 \cdot 2$ & $* *$ \\
\hline${ }^{15} \mathrm{~N}$ & 85 & $47^{\circ}$ & $45^{\text {bc }}$ & $39^{\mathrm{abc}}$ & $35^{a}$ & $42^{a b c}$ & $36^{a b}$ & 1.8 & $* *$ \\
\hline \multicolumn{10}{|l|}{ Rapeseed straw } \\
\hline NDF & 732 & $795^{\mathbf{a}}$ & $827^{a b}$ & $837^{a b}$ & $852^{b}$ & $832^{a b}$ & $828^{a b}$ & $10 \cdot 1$ & $*$ \\
\hline $\mathrm{N}$ & 5 & 4 & 5 & 5 & 4 & 3 & 4 & $0 \cdot 3$ & NS \\
\hline NDF-N & 397 & 459 & 440 & 555 & 573 & 528 & 495 & $50 \cdot 2$ & NS \\
\hline${ }^{15} \mathrm{~N}$ & 89 & 48 & 36 & 39 & 41 & 44 & 27 & $4 \cdot 9$ & NS \\
\hline
\end{tabular}

NS, not significant.

$a, b, c$ Means in the same row with different superscript letters were significantly different $(P \leqslant 0.05)$.

$* P \leqslant 0 \cdot 05, * * P \leqslant 0 \cdot 01, * * * P \leqslant 0.001$.

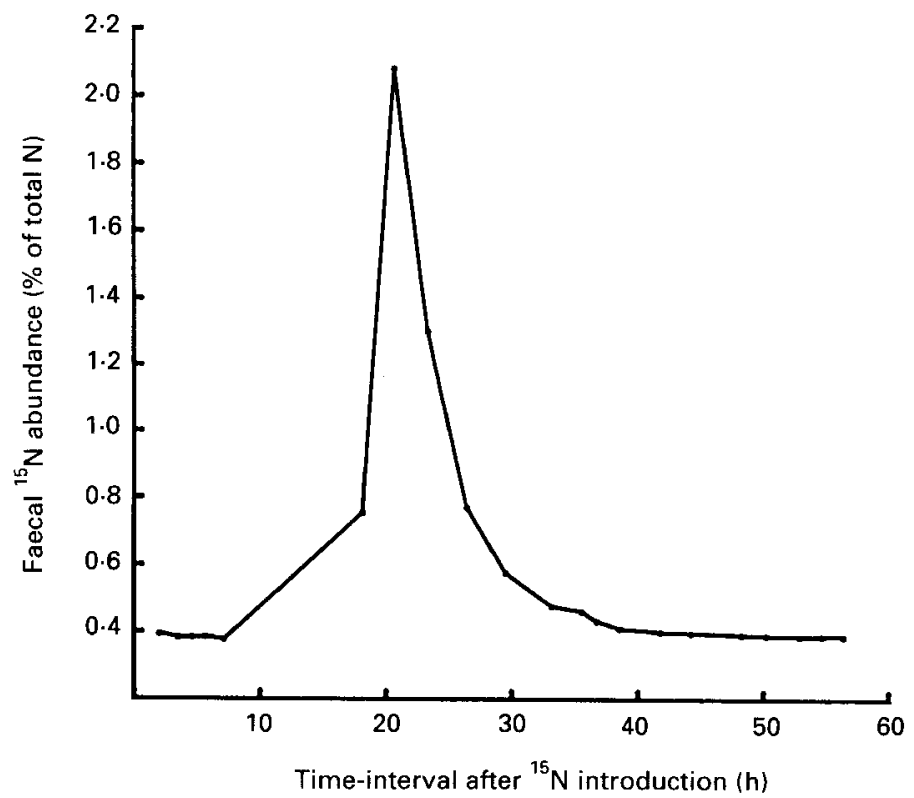

Fig. $1 .{ }^{15} \mathrm{~N}$ abundance in faeces collected during $56 \mathrm{~h}$ after the introduction of ${ }^{15} \mathrm{~N}$-labelled ryegrass (Lolium perenne) into the duodenum of a cow. For details of procedures, see p. 222. 
Table 3. Statistical significance of the effect of free surface area $\dagger(F)$ and pore size $\ddagger(P)$ of the bag cloth on the disappearance of dry matter $(D M)$, neutral-detergent fibre $(N D F)$, nitrogen, $N D F-N$ and ${ }^{15} N$ from the bags, and on the chemical composition of residual feeds§

\begin{tabular}{|c|c|c|c|c|c|c|c|c|}
\hline & \multicolumn{4}{|c|}{$\begin{array}{l}\text { Disappearance of feed } \\
\text { component }\end{array}$} & \multicolumn{4}{|c|}{$\begin{array}{l}\text { Chemical composition of } \\
\text { residual feed }\end{array}$} \\
\hline & $\begin{array}{l}\text { SEM } \\
\text { (df } 8)\end{array}$ & $\mathrm{F}$ & $\mathrm{P}$ & $\mathrm{F} \times \mathrm{P}$ & $\begin{array}{c}\text { SEM } \\
(\mathrm{df} 8)\end{array}$ & $\mathrm{F}$ & $\mathbf{P}$ & $\mathrm{F} \times \mathrm{P}$ \\
\hline \multicolumn{9}{|c|}{ Ryegrass (Lolium perenne) } \\
\hline DM & 11.9 & $* *$ & NS & NS & & & & \\
\hline NDF & $20 \cdot 3$ & NS & NS & NS & $9 \cdot 6$ & $* * *$ & NS & NS \\
\hline $\mathrm{N}$ & $33 \cdot 4$ & * & NS & NS & 1.7 & * & NS & NS \\
\hline NDF-N & $13 \cdot 6$ & * & NS & NS & $18 \cdot 5$ & NS & NS & NS \\
\hline${ }^{15} \mathrm{~N}$ & $34 \cdot 7$ & NS & NS & NS & $4 \cdot 2$ & NS & NS & NS \\
\hline \multicolumn{9}{|l|}{ Barley } \\
\hline DM & $12 \cdot 3$ & $* * *$ & $* * *$ & ** & & & & \\
\hline NDF & 8.7 & $* * *$ & ** & * & $24 \cdot 7$ & $* * *$ & $* *$ & NS \\
\hline $\mathrm{N}$ & $11 \cdot 3$ & $* * *$ & $* *$ & * & 0.3 & NS & NS & NS \\
\hline NDF-N & $16 \cdot 3$ & $* * *$ & NS & NS & $30 \cdot 1$ & $* * *$ & * & NS \\
\hline${ }^{15} \mathrm{~N}$ & $11 \cdot 1$ & $* * *$ & $* *$ & $*$ & 1.6 & NS & NS & NS \\
\hline \multicolumn{9}{|c|}{ Barley straw } \\
\hline DM & $8 \cdot 5$ & $* *$ & * & $*$ & & & & \\
\hline NDF & $5 \cdot 1$ & NS & NS & NS & $7 \cdot 0$ & $* *$ & ** & $*$ \\
\hline $\mathrm{N}$ & $33 \cdot 5$ & NS & NS & NS & $0 \cdot 2$ & NS & NS & NS \\
\hline NDF-N & $31 \cdot 1$ & NS & $* *$ & NS & $20 \cdot 9$ & NS & $* * *$ & $*$ \\
\hline${ }^{15} \mathrm{~N}$ & $11 \cdot 4$ & $* * *$ & $* * *$ & $*$ & 1.5 & $* * *$ & $\mathrm{NS}$ & NS \\
\hline \multicolumn{9}{|c|}{ Rapeseed (Brassica napus) straw } \\
\hline DM & $17 \cdot 9$ & NS & NS & NS & & & & \\
\hline NDF & $10 \cdot 8$ & NS & NS & NS & $11 \cdot 1$ & * & NS & NS \\
\hline $\mathrm{N}$ & 57.5 & * & NS & NS & 0.3 & * & NS & NS \\
\hline $\mathrm{NDF}-\mathrm{N}$ & $52 \cdot 3$ & NS & NS & NS & 53.6 & NS & NS & NS \\
\hline${ }^{15} \mathrm{~N}$ & $31 \cdot 2$ & * & NS & NS & $2 \cdot 7$ & NS & NS & $*$ \\
\hline
\end{tabular}

NS, not significant.

$* P \leqslant 0.05, * * P \leqslant 0.01, * * * P \leqslant 0 \cdot 001$.

†F $2 \%$ v. 5\%.

P small (1 or $6 \mu \mathrm{m}) v$. large $(10$ or $16 \mu \mathrm{m})$.

$\S$ Disappearance of feeds from the bags and chemical composition of feed residues are given in Tables 1 and 2 respectively.

The disappearance $(\mathrm{g} / \mathrm{kg})$ of components from ryegrass and barley often reached a maximum level with bags with a free surface area of $5 \%$ or more, irrespective of the pore size. With straw samples, differences between bags, if any, were more obvious between $2: 1$ and 2:10 bags (Table 1).

Intestinal digestion increased NDF $(\mathrm{g} / \mathrm{kg} \mathrm{DM})$ and, except for $\mathrm{N}$ with rapeseed straw in 2:10 and 5:6 bags, decreased $\mathrm{N}(\mathrm{g} / \mathrm{kg} \mathrm{DM})$ and ${ }^{15} \mathrm{~N}(\mathrm{~g} / \mathrm{kg} \mathrm{N})$ in the feeds. Residual NDF$\mathrm{N}(\mathrm{g} / \mathrm{kg} \mathrm{N})$ was clearly decreased with ryegrass, but was generally increased with barley, barley straw and rapeseed straw (Table 2). Generally, the effect of free surface area was more frequently significant than that of pore size for both disappearance of components and chemical composition of the feeds, when values were re-analysed factorially (Table 3 ).

The net loss within the intestine of excess ${ }^{15} \mathrm{~N}$ in ryegrass introduced into the duodenum was $70 \cdot 1 \%$.

\section{DISCUSSION}

It should be established that the values reported here for intestinal degradation or residual chemical composition of the feeds are not representative of ruminant digestion, because the 
experimental feeds were not exposed to rumen microbial degradation or abomasal digestion before intestinal digestion. Predigestion in the stomachs probably increases the total degradation of the feeds and possibly also changes their residual chemical composition. Also, the present results provide digestion estimates from one animal only. The degree or variation of degradation (or both) between replications obtained from more than one animal may have been significantly different from those presented here, due to variation in responses between animals. Therefore, methodological details involved in the bag technique rather than actual degradation values are emphasized in this discussion.

\section{Influence of bag cloth characteristics}

The lowest values for disappearance of feed components, as well as chemical composition of the residues, were mainly measured for bags with $2 \%$ free surface area ( 1 or $10 \mu \mathrm{m}$ pore size). Re-analysing values $2 \times 2$ factorially showed that, generally, free surface area significantly affected disappearance of the feed components from bags and also chemical composition of the residual feeds in the bags more often than pore size. Free surface area seemed to be a major determinant especially with disappearance of ryegrass and barley (Table 3). The disappearance of feeds from bags and the chemical composition of residual feeds in bags with a free surface of $5 \%$ or more were quite consistent, even with a smaller pore size of $6 \mu \mathrm{m}$ (Tables 1 and 2). Higher residual NDF content was repeatedly found in feeds from the bags with a free surface area of $5 \%$ or more, compared with bags with a free surface area of $2 \% . \mathrm{N}$ in ryegrass declined in the bags with a free surface area of $5 \%$ or more. Residual NDF-N in barley and rapeseed straw in bags with a free surface area of $5 \%$ was clearly higher than that in bags with a free surface area of $2 \%$. These results suggest that, within the given bag-cloth margins of $2: 1-33: 41 \% / \mu \mathrm{m}$, the free surface area rather than pore size seems to be the major determinant of the degradation of feeds in the intestinal nylon bag.

In this context, it seems relevant to comment on the possible influence of the free surface area of bag cloth on rumen degradation values obtained by the nylon-bag technique for ruminant feeds. The bags commonly used in rumen degradation studies have a pore size of $30-45 \mu \mathrm{m}$ and their free surface area varies, probably between 15 and $35 \%$ (e.g. Polymon, Zürich, Switzerland). Although disappearance from the intestinal nylon bags did not increase with an increasing free surface area:bag pore size $(\% / \mu \mathrm{m})$ from $5: 6$ to $33: 41$, the open (or closed) bag surface area may be a more important determinant in rumen degradation, because of the precondition of microbial attachment to the feeds before enzyme action. Closed bag surface areas of $65-85 \%$ in rumen bags probably restrict microbial invasion into the bags, attachment to the feeds therein, and consequently result in reduced microbial enzyme activity within the bags. Quantitatively, the influence of this physical barrier is difficult to assess, but it obviously might reduce rumen degradation estimates, especially with forages, compared with the true degradation of free floating feeds in the rumen. This suggestion is supported by recent findings (Huhtanen \& Khalili, 1989) that microbial carboxymethylcellulase or xylanase activities from grass silage residues collected from nylon bags are much lower than those in the same grass silage sampled from the rumen and washed by the same method.

\section{Disappearance of feed from mobile bags and the effect of residual non-feed $N$}

Barley and ryegrass DM disappearance from the bags was always markedly greater than the corresponding values for NDF; a similar trend was found with the straw samples. NDF in barley was more readily digested by intestinal enzymes than NDF in roughages. A DM disappearance of $1 \%$ unit corresponded, on average, with $0.43 \%$ unit NDF disappearance with roughages (Table 1), while with barley the corresponding value was 0.62 . This 
difference may be due to the hemicellulose : cellulose ratio being higher in intact barley than in roughages, and to probable differences in digestibility between these two components (Ulyatt et al. 1975).

The higher $\mathrm{N}$ disappearance from the bags as compared with the respective $\mathrm{DM}$ disappearance ( $N v$. DM, NDF-N v. NDF) demonstrates the high activity of intestinal enzymes in releasing $\mathrm{N}$ from feeds, as well as from fibre. Hvelplund (1985) and Voigt et al. (1985), using the mobile-bag technique, concluded that the extent of microbial digestion of feed $\mathrm{N}$ in the large intestine is small. However, Ulyatt et al. (1975) indicated a considerable potential of microbes to digest cellulose, hemicellulose, energy and protein in the large intestine. As the absorption mainly takes place in the small intestine, the site of digestion is decisive in determining the degree of absorption, i.e. in contributing to the nutritive value of the feeds. Therefore, more clarification is needed to proportionate the intestinal digestion of different feeds between small and large intestine.

${ }^{15} \mathrm{~N}$ as an internal marker in the feeds should indicate the true feed $\mathrm{N}$ in the residues (Varvikko \& Lindberg, 1985). Thus, ${ }^{15} \mathrm{~N}$ disappearance from the bags should correspond to the true feed $\mathrm{N}$ disappearance from the bags during intestinal exposure. ${ }^{15} \mathrm{~N}$ disappearance was greater than that of $\mathrm{N}$, the difference between these two being very dramatic with barley straw and rapeseed straw.

The difference between ${ }^{15} \mathrm{~N}$ and $\mathrm{N}$ indicates the presence of external $\mathrm{N}$ (either endogenous or microbial) in the residues. It can be calculated from Table 1 that external $\mathrm{N}$ in the residues reduces the feed $\mathrm{N}$ degradation from true (i.e. ${ }^{15} \mathrm{~N}$ disappearance) to apparent (i.e. $\mathrm{N}$ disappearance) by an average (mean of bags) of $61,29,368$ and $376 \mathrm{~g} / \mathrm{kg}$ in ryegrass, barley, barley straw and rapeseed straw, respectively. Similarly it can be calculated that the corresponding proportions of non-feed $\mathrm{N}$ were 274, 197, 527 and $562 \mathrm{~g} / \mathrm{kg}$ total residual $\mathrm{N}$. It can be concluded that, in the present experiment, estimating the feed $\mathrm{N}$ disappearance from the bags by using Kjeldahl $\mathrm{N}$ gave reasonably reliable estimates only for barley.

In an earlier study (Varvikko \& Vanhatalo, 1988) with intact or rumen-incubated hay or rumen-incubated grass silage, the disappearance of NDF-N from mobile bags was clearly higher than the corresponding value for total $\mathrm{N}$. In the present experiment NDF-N disappearance from ryegrass, being also clearly higher than $\mathrm{N}$ disappearance, was similar to the corresponding ${ }^{15} \mathrm{~N}$ disappearance from the bags (except for the $2: 1$ bag; Table 2). With straw samples, neither $\mathrm{N}$ nor NDF-N disappearance was similar to the corresponding ${ }^{15} \mathrm{~N}$ disappearance value.

\section{Intestinal net loss of feed ${ }^{15} \mathrm{~N} \mathrm{v}$. mobile-bag degradation}

In the present experiment, a net loss of $70.1 \%$ was obtained for excess ${ }^{15} \mathrm{~N}$ in ryegrass between the proximal duodenum and faeces. Voigt et al. (1985) reported a digestibility of $81.6 \%$ between the abomasum and the terminal ileum for ${ }^{15} \mathrm{~N}$-labelled crude protein $(\mathrm{N} \times 6.25)$ of freeze-dried ryegrass in cattle. The intestinal $\mathrm{N}$ digestibility value obtained by Voigt et al. (1985) was very similar to the disappearance of ryegrass $\mathrm{N}$ from bags in the present experiment (free surface area $5 \%$ or more), but was approximately $5 \%$ units lower than the corresponding values for ${ }^{15} \mathrm{~N}$ (Table 1).

The net loss of value for ${ }^{15} \mathrm{~N}$ between duodenum and faeces should represent the true intestinal digestion of ryegrass $\mathrm{N}$. The present value of $70.1 \%$ is, however, rather low compared with the value of $81.6 \%$ (Voigt et al. 1985). Differences in the experimental details might explain the discrepancy in the results between these two studies. Although the conclusions relating to the importance of pepsin treatment in the mobile-bag degradation of feed $\mathrm{N}$ are somewhat contradictory (Graham et al. 1985; Cherian et al. 1988), the higher $\mathrm{N}$ digestion value reported by Voigt et al. (1985) may emphasize the role of abomasal 
(pepsin) $\mathrm{N}$ digestion. On the other hand, the lower $\mathrm{N}$ digestion found in the present study may be partly attributed to the introduction, within a narrow range of time, of a bulk of ryegrass into the duodenum, which was biologically too large to be entirely digested by the intestinal enzymes.

According to the present findings using feed ${ }^{15} \mathrm{~N}$, disappearance of Kjeldahl $\mathrm{N}$ underestimates the true feed $\mathrm{N}$ degradation in the bags. The underestimate of feed $\mathrm{N}$ disappearance from the bags varies, analogous to the disappearance from nylon bags in the rumen, according to the type of feed, and is more evident with fibrous feeds with low $\mathrm{N}$ due to a proportionately large flow of 'intestinal' $\mathrm{N}$ into the bags. In degradation studies using the bag method, the free surface area of the bag cloth seems to be an important determinant of degradation values. It is possible that the mobile-bag method overestimates intestinal digestion of $\mathbf{N}$ or other nutrients because all of the material disappearing from the bags is probably not absorbed from the intestinal lumen. These conclusions should not, however, nullify the potential of the mobile-bag method as a handy tool for rapid relative comparisons of the intestinal digestibility of feeds.

The authors are indebted to Mrs Aino Matilainen and Mrs Anne Johansson for their technical assistance in this study. The ${ }^{15} \mathrm{~N}$ determinations were provided by the Institute of Plant Production, MTTK. The financial contribution by the Finnish feed industry is acknowledged.

\section{REFERENCES}

Cherian, C., Sauer, W. C. \& Thacker, P. A. (1988). Effect of predigestion factors on the apparent digestibility of protein for swine, determined by the mobile nylon bag technique. Journal of Animal Science 66, 1963-1968.

Graham, H., Aman, P., Newman, R. K. \& Newman, W. (1985). Use of a nylon-bag technique for pig feed digestibility studies. British Journal of Nutrition $\mathbf{5 4}, 719-726$.

Huhtanen, P. \& Khalili, H. (1989). Microbial polysaccharidase activities associated with rumen particulate material and feed particles incubated in nylon bags in the rumen. Asian-Australasian Journal of Animal Sciences $2,400-401$.

Hvelplund, T. (1984). Estimation of nitrogen digestibility in undegraded dietary protein by the in sacco procedure. Nuclear and Related Techniques in Animal Production and Health, pp. 641-643. Vienna: IAEA.

Hvelplund, T. (1985). Digestibility of rumen microbial protein and undegraded dietary protein estimated in the small intestine of sheep and by the in sacco procedure. Acta Agricultura Scandinavica 25, Suppl., 132-I44.

Kirkpatrick, B. K. \& Kennelly, I. J. (1985). The mobile bag technique as a predictor of the nutritive value of feedstuffs for dairy cattle. Agriculture and Forestry Bulletin, Special Issue, pp. 12-13, 64th Annual Feeders' Day Report. Alberta: University of Alberta.

Petry, H. \& Handlos, B. M. (1978). Untersuchungen zur Bestimmung der Verdaulichkeit von Náhrstoffen und Futterenergie mit Hilfe der Nylonbeutel-Technik beim Schwein. (Investigations for determining the digestibility of nutrients and feed energy using the nylon bag technique in swine.) Archiv für Tierernálhung $\mathbf{2 8}$, 531-543.

Rooke, J. A. (1985). The nutritive values of feed protein residues resistant to degradation by rumen microorganisms. Journal of the Science of Food and Agriculture 36, 629-637.

Sauer, W. C., den Hartog, L. A. \& Huisman, J. (1987). The evaluation of the mobile bag technique for measuring the protein digestibility of a wide variety of feedstuffs. Agriculture and Forestry Bulletin. Special Issue, pp. 24-25, 66th Annual Feeder's Day Report. Alberta: University of Alberta.

Sauer, W. C., Jorgensen, H. \& Berzins, R. (1983). A modified nylon bag technique for determining apparent digestibilities of protein in feedstuffs for pigs. Canadian Journal of Animal Science 63, 233-237.

Ulyatt, M. J., Dellow, O. W., Reid, C. S. \& Bauchop, T. (1975). Structure and function of the large intestine of ruminants. In Digestion and Metabolism in Ruminants, pp. 119-133 [I. W. McDonald and A. C. I. Warner, editors]. Armidale: University of New England Publishing Unit.

Van Soest, P. J. \& Wine, R. H. (1967). Use of detergents in the analysis of fibrous materials. IV. Determination of plant cell wall constituents. Journal of the Association of Official Agricultural Chemists 50, 50-55.

Varvikko, T. \& Lindberg, J. E. (1985). Estimation of microbial nitrogen in nylon-bag residues by feed ${ }^{15} \mathrm{~N}$ dilution. British Journal of Nutrition 54, 473-481. 
Varvikko, T. \& Vanhatalo, A. (1988). Intestinal nitrogen degradation in sacco of hay and grass silage. Proceedings VI World Animal Conference on Animal Production, Helsinki 1988, p. 359. Jyväskylä: Gummerus Oy kirjapaino.

Voigt, J. \& Piatkowski, B. (1983). Methode zur Untersuchung der Qualität des Futterproteins beim Wiederkäuer. Archiv für Tierernährung 33, 531.

Voigt, J., Piatkowski, B., Engelmann, H. \& Rudolph, E. (1985). Measurement of the postruminal digestibility of crude protein by the bag technique in cows. Archiv für Tierernährung 35, 555-562. 